\title{
Intersubject Interaction in Small Social Groups
}

\section{Інтерсуб'єктна взаємодія в малих соціальних групах}

Maria Nakonechna

Ph.D. in Psychology, Assistant Professor
Марія Наконечна

кандидат психологічних

наук, доцент

E-mail: maria.nakonechna2014@gmail.com orcid.org/0000-0002-2437-0853

Researcher ID: R-8145-2018

National Pedagogical Dragomanov University,

Kyiv, Ukraine

9, Pyrogova str.,

Kyiv, 01601
Національний педагогічний університет імені М. П. Дра-

голанова, м. Київ, Україна

вул. Пирогова, 9 ,

м. Київ, 01601

Original manuscript received December 12, 2018

Revised manuscript accepted January 23, 2019

\section{ABSTRACT}

The article proves that intersubject interaction is an important part of human psychical life, related to personal communications, actions for the good of others and internal growth. Cultural and historical psychology of L. S. Vygotsky is presented as methodological basis for intersubjectness research in the article. It is revealed that intersubjectness has strong correlations with semantic sphere of a personality.

The connection of intersubjectness with social and psychological features of a group (group belonging, psychological atmosphere) was studied with the use of questionnaires. Quite strong cross-correlations were found between studied variables (intersubjectness and social and psychological features of a group). The revealed empirical regularities and cross-correlations indirectly testify in behalf on that "The Questionnaire of Intersubjectness» (by 
M. M. Nakonechna) is a reliable and valid psycho-diagnostic instrument. In the process of experimental research with the modified methodology of psychical satiation it was proved that a situation of intersubject co-operation largely influenced on the origin of positive experiencing during monotonous activities. Four-stages experimental research was analyzed in order to carry out answers for the following research questions: 1) Does the sense incorporation make any changes to the process of monotonous activities? 2) How does intersubject co-operation influence on an activity causing psychical satiation? 3) In what way will the sense of co-operating with others, sense of professional perfection, sense of work etc. influence on activities of monotonous crosses drawing? It is proved that a situation of intersubject co-operation is perceived by participants in a totally different way than a situation of individual, monosubject activities. It is found that experiencing during intersubject co-operation was characterized by a positive emotional background. The hypothesis on new senses restructurize monotonous activity was confirmed.

Key words: intersubject co-operation, sense, activity, personality, intercourse, group.

\section{Вступ}

Інтерсуб'єктна взаємодія як особлива форма інтеракції, результатом якої є зростання рівня суб’єктності учасників, виконує важливі функції у людському суспільстві. Тому особливо важливо вивчати різні аспекти такої взаємодії з точки зору психологічної науки, що уможливить не тільки науковий поступ, але також зв'язок досліджень із реальною практикою надання психологічної допомоги.

М. Дафермос дослідив культурно-історичну теорію Л. С. Виготського в світлі ідей діалектики (Dafermos, 2018). Це є цінним для нашого дослідження, адже дозволяє глибше зрозуміти ключові ідеї «непрочитаного класика» Л. С. Виготського дуже часто цитують, але не читають так активно, як цього заслуговує творча спадщина автора. Методологеми Л. С. Виготського, зокрема його закон про психічну функцію, яка «з’являється на сцені двічі» (Выготский, 2015) - спочатку як інтерпсихологічна, а потім як інтрапсихологічна функція, стали основними орієнтирами в нашому дослідженні. 
У дослідженні П. Піффа, П. Дітзе, М. Фейберга, Д. Станкато і Д. Келтнера (Piff, Dietze, Feinberg, Stancato \& Keltner, 2015) було показано, що захоплення та здивування (awe) стимулюють просоціальну активність людей i загалом зацікавленість у питаннях, важливих для суспільства. Зокрема, переживання захоплення та здивування провокували більшу щедрість і залученість до ситуацій, де потрібно зробити щось на користь іншої людини. Це показує важливість урахування емоційно-мотиваційних аспектів інтерсуб'єктної взаємодії та необхідність детальнішого дослідження впливу таких переживань, як захоплення та здивування, на реальний перебіг інтерсуб'єктної взаємодії людей.

Дж. Стеллар і Р. Віллер дослідили, як інформація про моральні вчинки людини впливає на сприйняття компетентності цієї людини (Stellar \& Willer, 2018). Це доводить, що різні аспекти інтерсуб'єктної взаємодії на свідомому і навіть на несвідомому рівнях можуть визначати те, як ми сприймаємо інших людей та інтерпретуємо їх вчинки. Зокрема, вибори особистості в бік суспільно схвалюваних моральних вчинків можуть сприяти тому, що в інтерсуб’єктній взаємодії ця особистість сприйматиметься як більш досвідчена та компетентна (Stellar \& Willer, 2018).

I. С. Булах проаналізувала критерії особистісного зростання людини в онтогенезі та виявила, що значна їх кількість пов'язана з увагою до інших людей, діями на користь інших, урахуванням суб'єктної позиції співрозмовника (словами Г. Міда - «Узагальненого Іншого») (Булах, 2018). Отже, критерії особистісного зростання тісно пов'язані 3 інтерсуб’єктною взаємодією людей.

Розвиваючи ідею особистісного спілкування, яке феноменологічно є надзвичайно близьким до інтерсуб'єктної взаємодії, М. І. Бобнєва зазначає: «У цих умовах людина засвоює основну норлу особистісного спілкування - необхідність перетворення відпочаткової здатності до воління у людську «добру волю», без чого немислиме ніяке особис- 
тісне спілкування. Істотним є те, що «добра воля» повинна бути спрямована не тільки і не стільки на іншу особу партнера по спілкуванню, скільки на саму особистість, яка проявляє волю» (Бобнева, 1981: 259). Тут ми бачимо тісне переплетіння вольового, мотиваційного та морально-етичного компонентів психіки людини. Людина може ставити перед собою будь-які цілі, але лише частина з них будуть морально-етично виправданими. І тоді важливо звертатися не до іншої людини, а до самого себе, власної совісті, власного морального імперативу (І. Кант (Кант, 2000)). Щодо інтерсуб'єктної взаємодії це означає, що предметом такої взаємодії є певні смисли, й інколи навіть аморальні смисли та наміри можуть надихати і вселяти ентузіазм. Але водночас слід наголосити, що тільки включеність смислів інтерсуб'єктної взаємодії в сферу моралі й етики може бути дійсною передумовою справжнього розвитку людини як суб'єкта. Тут важливою стає така характеристика інтерсуб'єктності, як рефлексивність: людина повинна розмірковувати щодо того, який моральний сенс взаємодії, i до чого призводить її спонукальний характер. Тільки морально-етично прийнятні цілі, народжені в межах інтерсуб'єктної взаємодії, можуть дійсно розвивати людину як суб'єкта й особистість, в іншому ж випадку мова може йти тільки про псевдорозвиток.

Із цього приводу С. О. Ставицька писала: «Отже, духовний розвиток людини, а, відповідно, і розвиток їі духовної самосвідомості відбувається поетапно і включає в себе ієрархічно вибудувані структурні компоненти, зокрема емоційний, пізнавальний, моральний, поведінковий, що визначає загальну й індивідуальну динаміку духовного розвитку людини, включеної у певний життєвий контекст» (Ставицька, 2011: 172). Отже, компонентами розвитку людини та її духовної самосвідомості С. О. Ставицька вважає емоційні, пізнавальні, моральні та поведінкові складові, й це є принциповим у розумінні запропонованої авторкою теоретичної моделі. Проблеми співвідношення 
моралі й особистості, норм і свободи, вибору та можливостей - це важливі проблеми сучасної психологічної науки, людинознавства загалом. На вістрі різних варіантів вирішення цих проблем створюються концепції та теорії, які в континуумах від абсолютного до часткового, від детермінізму до індетермінізму утворюють свої специфічні конфігурації. Для нас важливо, що інтерсуб'єктна взаємодія як реальна форма взаємодії людей може створити виклик - i моралі, і нормам, і свободі, і можливостям людини. I те, як людина прийматиме цей виклик, як вона його долатиме, $\mathrm{i}$ визначатиме можливості особистісного розвитку людини.

Мета статті - дослідити соціально-психологічні особливості інтерсуб’єктної взаємодії.

\section{Завдання статті}

1. Проаналізувати психологічні аспекти інтерсуб'єктної взаємодії, зокрема, пов'язані з особистісним спілкуванням і смисловою сферою людини.

2. Емпірично вивчити взаємозв'язок інтерсуб'єктності $з$ соціально-психологічними характеристиками групи (груповою приналежністю, психологічною атмосферою).

3. Експериментально дослідити психологічні особливості інтерсуб'єктної взаємодії в умовах монотонної діяльності та вплив нових сенсів на виконувані одноманітні дії.

\section{Емпіричне дослідження 1 Методи та методики дослідження}

Для емпіричного дослідження було обрано психологічні опитувальники. Першою методикою стала розроблена нами «Методика діагностики інтерсуб'єктності» (М. М. Наконечна). Методика знаходиться на етапі стандартизації (Наконечна, 2017), і попередні дослідження засвідчили достатні показники придатності методики (альфа Кронбаха становить 0,777). Друга методика - визначення індексу групової приналежності Сішора, а третя - методика діагностики психологічної атмосфери в колективі 
Ф. Фідлера. Були отримані дані 103 студентів Ніжинського державного університету імені Миколи Гоголя. Серед досліджуваних були студенти денної форми навчання - 89 осіб, заочної форми навчання - 14 осіб; студенти I курсу 29, II курсу - 41, III курсу - 8, IV курсу - 16, магістратури - 9 осіб; студенти факультету іноземних мов -44 особи, факультету психології та соціальної роботи - 28 осіб, природничо-географічного факультету - 31 особа. Дані психологічних опитувальників було піддано кореляційному аналізу (коефіцієнт кореляції Спірмена).

\section{Результати та дискусії}

Дані емпіричного дослідження було піддано статистичному аналізу. За «Методикою діагностики інтерсуб'єктності» (М. М. Наконечна) на досліджуваній вибірці наявні такі показники: середньоарифметичне - 68,07; мода - 71; медіана - 70; мінімальне значення, зафіксоване емпірично - 38 (у той час як потенційно можливе мінімальне значення - 16); максимальне значення - 80 (співпадає з максимально можливим); середньоквадратичне відхилення 7,35. Близькі значення моди, медіани та середньоарифметичного значення вказують на нормальний розподіл даних у досліджуваній вибірці. Водночас наявна тенденція до високих показників середньоарифметичного значення, що може бути пов'язано не тільки з реальним високим рівнем інтерсуб'єктності досліджуваних, але й із соціальною бажаністю відповідей.

За результатами проведення методики для визначення індексу групової приналежності Сішора отримано такі показники: середньоарифметичне - 14,27; мода - 15; медіана - 15; мінімальне значення - 7; максимальне - 21; середньоквадратичне відхилення - 2,74. Досліджувані нами студентські групи за результатами методики Сішора мають рівень групової згуртованості вищий середнього. Близькі значення моди, медіани та середньоарифметичного значення, а також низькі значення середньоквадратичного відхи- 
лення свідчать про уніфікованість відповідей досліджуваних. Крім того, можна припустити, що існує взаємозв’язок між рівнем групової згуртованості й інтерсуб'єктною взаємодією, діагностованою за допомогою «Методики діагностики інтерсуб'єктності» (М. М. Наконечна).

За методикою діагностики психологічної атмосфери у колективі Ф. Фідлера наявні такі результати: середньоарифметичне - 34,73; мода - 21; медіана - 34; мінімальне значення - 10; максимальне - 74; середньоквадратичне відхилення - 13,87. Результати методики показали середньо-позитивну психологічну атмосферу в досліджуваних групах (результати могли розподілитися від 10 до 80, де 80 - найнесприятливіша психологічна атмосфера). Слід зауважити, що статистична обробка даних показала різницю між модою та медіаною і середньоарифметичним значенням (21 і 34), що може свідчити про різні показники психологічної атмосфери у різних досліджуваних групах. На цей самий факт указує і досить високе середньоквадратичне відхилення.

Аналіз отриманих даних був проведений також за окремими досліджуваними студентськими групами. Результати представлені у табл. 1.

Усього було досліджено 8 студентських груп. Загальною закономірністю є те, що чим вища згуртованість (за методикою Сішора), тим кращі показники психологічної атмосфери (за методикою Фідлера) (при цьому кращі показники - це більш низькі показники методики Фідлера, адже саме низькі показники в цій методиці відповідають більш гармонійній психологічній атмосфері). Наприклад, у досліджуваної групи 5 (n = 16) найнижчі показники згуртованості $(12,56$ за методикою Сішора), що супроводжуються найвищими показниками дисгармонійності психологічної атмосфери (46 за методикою Фідлера). Цікаво, що водночас цій групі притаманні найнижчі за досліджуваною нами вибіркою показники інтерсуб'єктності $(62,75$ за методикою «Методика діагностики інтерсуб’єктності» М. М. Нако- 
нечної). Це цілком виправдано, адже інтерсуб'єктність не стабільна особистісна риса, а, швидше, характеристика процесу міжособистісної взаємодії. При цьому інтерсуб'єктність тісно взаємопов'язана саме з психологічною атмосферою та згуртованістю групи, оскільки саме в цих умовах проходить інтерсуб’єктне спілкування.

Таблиця 1. Показники згуртованості, психологічної атмосфери й інтерсуб'єктності в різних досліджуваних групах

\begin{tabular}{|c|c|c|c|c|c|c|c|}
\hline \multirow{2}{*}{ 总 } & \multirow{2}{*}{ 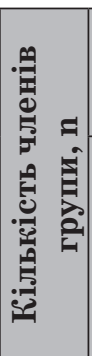 } & \multicolumn{2}{|c|}{$\begin{array}{c}\text { Згуртованість } \\
\text { (за методикою } \\
\text { Сішора) }\end{array}$} & \multicolumn{2}{|c|}{$\begin{array}{c}\text { Психологічна ат- } \\
\text { мосфера (за мето- } \\
\text { дикою Фідлера) }\end{array}$} & \multicolumn{2}{|c|}{$\begin{array}{c}\text { Інтер- } \\
\text { суб’єктність }\end{array}$} \\
\hline & & $\begin{array}{l}\text { Серед- } \\
\text { ньо- } \\
\text { арифме- } \\
\text { тичне }\end{array}$ & $\begin{array}{c}\text { Серед- } \\
\text { ньо-ква- } \\
\text { дратич- } \\
\text { не від- } \\
\text { хилення }\end{array}$ & $\begin{array}{c}\text { Серед- } \\
\text { ньо- } \\
\text { арифме- } \\
\text { тичне }\end{array}$ & $\begin{array}{c}\text { Серед- } \\
\text { ньо-ква- } \\
\text { дратич- } \\
\text { не від- } \\
\text { хилення }\end{array}$ & $\begin{array}{l}\text { Серед- } \\
\text { ньо- } \\
\text { арифмме- } \\
\text { тичне }\end{array}$ & $\begin{array}{c}\text { Серед- } \\
\text { ньо-ква- } \\
\text { дратич- } \\
\text { не від- } \\
\text { хилення }\end{array}$ \\
\hline 1. & 17 & 14,76 & 2,56 & 27,94 & 11,51 & 70,06 & 7,46 \\
\hline 2. & 15 & 15 & 2,59 & 33,33 & 15,37 & 67,53 & 8,89 \\
\hline 3. & 11 & 14,73 & 2,19 & 31,82 & 12,11 & 71,73 & 6,93 \\
\hline 4. & 3 & 14,33 & 0,58 & 32,33 & 13,5 & 64,67 & 3,51 \\
\hline 5. & 16 & 12,56 & 2,22 & 46 & 10,6 & 62,75 & 7,23 \\
\hline 6. & 3 & 15,67 & 1,15 & 35 & 2,65 & 68 & 4,58 \\
\hline 7. & 11 & 13,73 & 3,17 & 30,9 & 12,32 & 66,27 & 5,04 \\
\hline 8. & 27 & 14,44 & 3,32 & 36,07 & 15,17 & 69,89 & 6,5 \\
\hline
\end{tabular}

Найвищі показники згуртованості (14,76 за методикою Сішора) можемо спостерігати у групи $1(\mathrm{n}=17)$. Водночас у цієї групи найнижчі показники $(27,94)$ за методикою Фідлера, що відповідає найбільш сприятливій і гармонійній психологічній атмосфері. Показники цієї групи за «Mетодикою діагностики інтерсуб'єктності» $(70,06)$ - другі за величиною серед середньоарифметичних значень восьми досліджуваних груп. Знову ж, це є одним із доказів взаємозв'язку інтерсуб'єктності з соціально-психологічними ха- 
рактеристиками групи (зокрема, згуртованістю та психологічною атмосферою).

Кореляційний аналіз (коефіцієнт кореляції Спірмена) показав такі взаємозв'язки. Чим більший рівень інтерсуб'єктності, тим вищі показники гармонійної психологічної атмосфери в колективі за методикою Ф. Фідлера $(\mathrm{r}=-0,493, \mathrm{p}<0,001)$. Тут маємо негативний кореляційний взаємозв'язок інтерсуб'єктності з психологічною атмосферою, але водночас за методикою Ф. Фідлера вищі бали означають більш негативну психологічну атмосферу, тоді як за методикою інтерсуб'єктності вищі бали означають вищий рівень прояву інтерсуб'єктності. Такий кореляційний зв’язок може бути пояснений тим, що інтерсуб'єктність припускає врахування суб'єктної позиції інших людей i водночас вияв власної суб'єктної позиції, а це може призводити до вищих показників гармонійності психологічної атмосфери.

Інтерсуб’єктність має позитивний кореляційний зв'язок з індексом групової приналежності Сішора ( $\mathrm{r}=0,421$, $\mathrm{p}<0,001)$. Іншими словами, чим вищий рівень розвитку інтерсуб'єктності, тим більше людина відчуватиме власну групову приналежність. Але при цьому, враховуючи результати негативного кореляційного зв'язку інтерсуб'єктності з психологічною атмосферою, людина не обов'язково відчуватиме себе більш комфортно та захищено в колективі. Водночас може прослідковуватись і така закономірність: чим вищий рівень групової приналежності людини, тим більшою мірою ця людина буде схильна залучатися до розвиненої інтерсуб'єктної взаємодії.

Негативно корелюють між собою індекс групової приналежності Сішора та показники психологічної атмосфери в колективі за методикою Ф. Фідлера $(\mathrm{r}=-0,538, \mathrm{p}<0,001)$. Це легко пояснити тим, що методики мають різноспрямовані показники - за методикою Ф. Фідлера нижчі бали означають більш гармонійну атмосферу, тоді як за методикою Сішора вищі бали означають вищий рівень групової прина- 
лежності. Тісний взаємозв'язок психологічної атмосфери та групової приналежності пояснюється соціально-психологічними закономірностями функціонування групи, вже описаними та поясненими в науковій літературі (Татенко, 2003; Зайчикова, 2005). Виявлені нами емпіричні закономірності та кореляційні зв'язки свідчать на користь того, що «Методика дослідження інтерсуб’єктності» М. М. Наконечної є надійним і валідним психодіагностичним інструментом. Утім, детальна стандартизація методики 3 перевіркою їі надійності, валідності й точності потребує спеціальних емпіричних і теоретичних досліджень.

У дослідженні Бредлі, Постлесвайта, Клотца, Хамдані та Брауна (Bradley, Postlethwaite, Klotz, Hamdani \& Brown, 2012) було виявлено, що психологічний клімат i психологічна безпека покращують вирішення конфліктних завдань у групах. Це перегукується з результатами нашого дослідження, у якому аналізувалися взаємозв'язки згуртованості та психологічного клімату в групі з інтерсуб’єктністю.

\section{Емпіричне дослідження 2}

\section{Методи та методики дослідження}

Методом нашого емпіричного дослідження став експеримент, який проводився у трьох студентських групах (n = 38). У ході експериментального дослідження була модифікована методика дослідження «психічного насичення», запропонована та проведена Л. С. Славіною (Славина, 1969) у рамках методології К. Левіна (Левин, 2000). У класичних дослідженнях Л. С. Славіної дітям пропонували одноманітну діяльність (ставити крапки у кружечки). На другому етапі експериментатор усіляко намагався заохотити дітей продовжувати цю діяльність, а на третьому етапі ставилася мета - зробити конкретну кількість кружечків, і не більше. Було показано, що мета суттєво змінює діяльність. У наших дослідженнях експеримент складався 
3 чотирьох етапів. Ідея цього експериментального дослідження належить доктору психологічних наук, профресору М. В. Папучі (Папуча, 2011). Експеримент проведений i проаналізований М. М. Наконечною.

На першому етапі досліджуваних просили ставити хрестики в клітинках. У трьох досліджуваних групах час, упродовж якого студенти ставили одноманітні хрестики, варіював від 10 до 14 хвилин. На другому етапі експериментатор просив досліджуваних більш вільно підійти до малювання хрестиків - можна було малювати хрестиками будинки, візерунки, все, що завгодно. Тривалість цього етапу варіювала від 12 до 16 хвилин. Етапи проходили один за одним, перерв між ними не було. На третьому етапі досліджуваних просили об'єднатися в пари або трійки i разом малювати хрестики. На цьому етапі специфічно досліджувалися особливості інтерсуб'єктної взаємодії, яка могла б допомогти подолати негативні прояви монотонної діяльності. Цей етап у трьох досліджуваних нами групах тривав від 13 до 18 хвилин. На четвертому етапі досліджуваних просили продовжити самостійно малювати хрестики, при цьому експериментатор казав, що розкаже про цю методику, і студенти зможуть зрозуміти, як можна їі використовувати, наприклад, у психодіагностичній роботі 3 дітьми (вводився професійно-орієнтований смисл виконуваної монотонної діяльності). Цей етап тривав у досліджуваних нами групах від 9 до 11 хвилин.

Отже, запропоноване нами експериментальне дослідження містило чотири етапи та припускало віднайдення відповідей на такі дослідницькі запитання: 1) Чи змінює зміна сенсу процес виконання монотонної діяльності? 2) Як інтерсуб’єктна взаємодія впливає на перебіг діяльності, що викликає психічне насичення? 3) Який із сенсів сенс взаємодії з іншим, сенс професійного удосконалення, сенс більшої свободи виконуваної діяльності - найбільше впливатиме на діяльність малювання одноманітних хрестиків? 


\section{Результати та дискусії}

У ході експерименту досліджувані ставили запитання, наприклад: «У чому сутність завдання?», «Чи скажете Ви, коли досить?», «Ставити по горизонталі чи по вертикалі?» Експериментатор відповідав на ці запитання: «Я поясню потім», «Ще багато часу», «Можна і так, і так». Сутність відповідей полягала у створенні певної невизначеності завдання. На другому етапі всі студенти почали малювати 3 більшою свободою, почали переговорюватися між собою, сміятися. Лише один досліджуваний із 38 перейшов до рутинних хрестиків у рядочок.

На третьому етапі, коли досліджувані мусили працювати в ході інтерсуб’єктної взаємодії, у мікрогрупах хтось, зазвичай, пропонував ідею, що саме намалювати - наприклад, сердечко, кораблик, будиночок, мишку, квіточку. Спостерігалися різні типи взаємодії: мовчазна; з посмішками і гумором. Сміялися хоч раз у всіх підгрупах. Була циклічність взаємодії: цикли мовчання змінювалися циклами розмов і сміху. На четвертому етапі, де у процесі малювання хрестиків пропонувалося покращити себе як професіонала, студенти перейшли до індивідуальних діяльностей. У 3 мікрогрупах із 16 досліджувані продовжували перемовлятися. 4 студенти ставили хрестики підряд, 34 робили візерунки, малюнки з хрестиків. При цьому можна припустити, що студенти, які повернулися до хрестиків «підряд», зробили це на якісно іншому рівні, наситивши свою потребу в смислі.

Після експерименту зі студентами проводилася бесіда. Зокрема, сталося таке запитання: «На якому з етапів експерименту було найлегше і найцікавіше працювати? Чому? Коли було найменш цікаво?» Відповіді студентів розподілилися між тим, що найлегше і найцікавіше на II етапі (з більшою свободою виконуваної діяльності) - 42\% , III (при інтерсуб'єктній взаємодії) - 29\% і IV етапі (із сенсом професійного самовдосконалення) - 29\%. Студенти відповідали так: «Найцікавіше, коли пари працювали, креатив 
зашкалював» ; «Найпростіше на II етапі, коли з’являється сенс, а найважче на I етапі, бо одноманітна робота, хочеться їі урізноманітнити»; «Перший етап найбільш монотонний і нудний. Було цікаво працювати в парі»; «Не було складно ніде, а найцікавіше було на IV етапі. Я не бачу сенсу роботи, коли не розумію, заради чого. На IV етапі була рефлексія, розкриття самого себе. Почала думати. Було цікаво працювати в парі»; «Найлегше і найцікавіше було на III етапі, моя увага розсіювалася, я дослухалася до дівчат. Найважчим був I етап, бо набридло ставити ці хрестики»; «Найскладніше на IV етапі. Найцікавіше на II етапі. I і III етапи доволі нескладні й доволі цікаві» .

Проведене експериментальне дослідження дало змогу виявити дві основні закономірності. По-перше, ситуація інтерсуб’єктної взаємодії сприймається учасниками принципово по-іншому, ніж ситуація одноосібної, моносуб'єктної діяльності. У нашому дослідженні особливості інтерсуб’єктної взаємодії полягали в тому, що така взаємодія приносила радість, задоволення, сміх, зацікавленість - іншими словами, різні позитивні емоції. Отже, переживання в ході інтерсуб'єктної взаємодії характеризувалися позитивним емоційним тлом. Іншою особливістю інтерсуб'єктної взаємодії стало те, що в ній поєднувалися інтерсуб'єктність (за характеристикою включеності кількох учасників) та осмисленість - у більшості випадків досліджувані пропонували малювати хрестики з певним сенсом, робити візерунки, схеми, чергуватися при малюванні хрестиків.

По-друге, дуже важливим психологічним засобом подолання монотонної, одноманітної діяльності є віднайдення нового сенсу. На різних етапах експерименту таким сенсом ставали сенс взаємодії з іншим, сенс професійного удосконалення, сенс свободи. Дослідження показало, що всі ці сенси мали вплив на перебіг і рефлексію над виконуваною монотонною діяльністю. Іноді сенси поєднувалися - під час взаємодії з іншим включався сенс творчості, й 
досліджувані разом починали придумувати, як по-новому малювати хрестики.

Проведене нами дослідження принципово відрізняється від експериментів Л. С. Славіної (Славина, 1969): 1) ставилася інша дослідницька мета; 2) інша вікова група (студенти, а не дошкільники); 3) інший характер завдань (різний зміст етапів експерименту). Дослідження дало змогу виокремити деякі психологічні закономірності інтерсуб’єктної взаємодії та впливу на монотонну діяльність нового сенсу. Основним методологічним орієнтиром нашого експериментального дослідження стали положення культурно-історичної психології Л. С. Виготського (Выготский, 2015) та ідея про те, що експеримент може бути дослідницьким i формувальним водночас. Подальшого вивчення потребує аналіз мікрогенезу інтерсуб'єктної взаємодії, тобто психологічне дослідження мікрозмін у процесі включеності людей у ситуацію взаємного суб'єктного розвитку.

Були досліджені такі соціально-психологічні характеристики інтерсуб'єктної взаємодії: 1) зміна динаміки виконуваної монотонної діяльності від факту включення в мікрогрупи; 2) залежність характеру виконуваної спільно діяльності від сенсу (професійного зростання, взаємодії 3 іншим, свободи в здійсненні дій); 3) емоційне тло виконання монотонної діяльності в мікрогрупах характеризувалося більш позитивними пережкиваннями.

\section{Висновки}

Інтерсуб'єктна взаємодія - це важлива частина психічного життя людини, пов'язана з особистісним спілкуванням, діями на благо інших та внутрішнім зростанням. Основою для дослідження інтерсуб'єктності в нашому дослідженні стала культурно-історична психологія Л. С. Виготського. Інтерсуб'єктність має тісні зв' язки зі смисловою сферою особистості.

Був досліджений взаємозв'язок інтерсуб'єктності з соціально-психологічними характеристиками групи (гру- 
повою приналежністю, психологічною атмосферою) 3 використанням опитувальників. Виявлені досить сильні кореляційні зв'язки між досліджуваними змінними (інтерсуб'єктністю та соціально-психологічними особливостями групи). У процесі експериментального дослідження з модифікованою методикою психічного насичення було доведено, що ситуація інтерсуб'єктної взаємодії значною мірою впливає на виникнення позитивних переживань під час монотонної діяльності. Виявлено, що виконання монотонної діяльності в ситуації міжособистісної взаємодії проходить суттєво по-іншому, ніж у ситуації одноосібної діяльності. Підтверджена також гіпотеза про те, що введення нових сенсів переструктуровує виконувану одноманітну діяльність.

Перспективи подальших досліджень пов'язані зі стандартизацією опитувальника «Методика дослідження інтерсуб’єктності» та вивченням інтерсуб'єктності у реальних ситуаціях взаємодії людей.

\section{Література}

Бобнева М. И. Нормы общения и внутренний мир личности. Проблема общения в психологии / Отв. ред. Б. Ф. Ломов. Москва : Издательство «Наука», 1981. С. 241-264.

Булах I. С. Методологічні проблеми визначення критеріїв особистісного зростання людини в онтогенезі. Науковий часопис Національного педагогічного університету імені М. П. Драгоманова. Серія 12: Психологічні науки. 2018. Вип. 7 (52). С. 5-14.

Выготский Л. С. Полное собрание сочинений. Т. 1. Москва, 2015. 747 с.

Зайчикова Т. В. Соціально-психологічні детермінанти синдрому «професійного вигорання» у вчителів : автореф. дис. ... канд. психол. наук : спец. 19.00.05. Київ, 2005. 20 с.

Кант I. Критика чистого розуму. Київ : Юніверс, 2000. 504 с.

Левин К. Теория поля в социальных науках. Санкт-Петербург : «Сенcop», 2000. $368 \mathrm{c}$.

Наконечна М. М. Інтерсуб'єктна взаємодія як баланс свободи та структури [Електронний ресурс]. Психологічний часопис. 2017. № 10 (6). C. 107-116. Режим доступу : http://www.apsijournal.com/index. $\mathrm{php} / \mathrm{psyjournal} /$ article/view/170.

Папуча М. В. Внутрішній світ людини та його становлення: [наукова монографія]. Ніжин : Видавець Лисенко М. М., 2011. 656 с. 
Славина Л. С. Ограничение объема работы как условие ее выполнения в состоянии «пресыщения». Вопросы психологии. 1969. № 2. C. 34-42.

Ставицька С. О. Духовна самосвідомість особистості: становлення і розвиток в юнацькому віці: монографія. Київ : НПУ імені М. П. Драгоманова, 2011. 727 с.

Татенко В. Соціально-психологічні механізми впливу людини на людину. Соціальна психологія. 2003. № 1. С. 60-72.

Bradley, B., Postlethwaite, B., Klotz, A., Hamdani, M. , \& Brown, K. (2012). Reaping the Benefits of Task Conflict in Teams: The Critical Role of Team Psychological Safety Climate. Journal of Applied Psychology, 1, Vol. 97, 151-158. DOI 10.1037/a0024200.

Dafermos, M. (2018). Rethinking Cultural-Historical Theory: A Dialectical Perspective to Vygotsky. Singapore : Springer Nature Singapore Pte Ltd.

Piff, P., Dietze, P., Feinberg, M., Stancato, D., \& Keltner, D. (2015). Awe, the Small Self, and Prosocial Behavior. Journal of Personality and Social Psychology, 6, Vol. 108, 883-899. Retrieved from http:// dx.doi.org/10.1037/pspi0000018.

Stellar, J., Willer, R. (2018). Unethical and Inept? The Influence of Moral Information on Perceptions of Competence. Journal of Personality and Social Psychology, 2, Vol. 114, 195-210. Retrieved from http:// dx.doi.org/10.1037/pspa0000097.

\section{References}

Bobneva, M. I. (1981). Normy obshchenija i vnutrennij mir lichnosti [Communicational norms and personality's inner world]. Problema obshchenija $v$ psihologii - Problem of Communication in Psychology (pp. 241-264). Moskva : Izd-vo «Nauka» [in Russian].

Bulakh, I. S. (2018). Metodolohichni problemy vyznachennia kryteriiv osobystisnoho zrostannia liudyny $\mathrm{v}$ ontohenezi [Methodological problems of determining the criteria of personal growth during ontogenesis]. Naukovyi chasopys Natsionalnoho pedahohichnoho universytetu imeni M. P. Drahomanova. Seriia 12: Psykholohichni nauky - Scientific Journal of National M. P. Dragomanov Pedagogical University. Issue 12. Psychological Sciences, 7 (52), 5-14 [in Ukrainian].

Vygotskij, L. S. (2015). Polnoe sobranie sochinenij [Complete collected works ]. Vol. 1. Moskva [in Russian].

Zaichykova, T. V. (2005). Sotsialno-psykholohichni determinanty syndro$\mathrm{mu}$ «profesiinoho vyhorannia» $\mathrm{u}$ vchyteliv [Social and psychological determinants of "professional burn-out» syndrome among teachers]. Extended abstract of candidate's thesis. Kyiv [in Ukrainian].

Kant, I. (2000). Krytyka chystoho rozumu [Critique of Pure Reason]. Kyiv : Univers [in Ukrainian]. 
Levin, K. (2000). Teorija polja $v$ social'nyh naukah [Field theory in social science]. Sankt-Peterburg : «Sensor» [in Russian].

Nakonechna, M. M. (2017). Intersubiektna vzaiemodiia yak balans svobody ta struktury [Intersubject interaction as a balance of freedom and structure]. Psykholohichnyi chasopys - Psychological Journal, 10 (6), 107-116. Retrieved from http://www.apsijournal.com/index.php/psyjournal/article/view/170 [in Ukrainian].

Papucha, M. V. (2011). Vnutrishnii svit liudyny ta yoho stanovlennia [The human inner world and its becoming]. Nizhyn : Vydavets Lysenko M. M. [in Ukrainian].

Slavina, L. S. (1969). Ogranichenie objema raboty kak uslovie eje vypolnenija v sostojanii "presyshchenija» [The limitation of the work's amount as a condition of its fulfillment in the "satiation» state]. Voprosy psihologii - Questions on Psychology, 2, 34-42 [in Russian].

Stavytska, S. O. (2011). Dukhovna samosvidomist osobystosti: stanovlennia $i$ rozvytok $v$ yunatskomu vitsi [Spiritual selfconsciousness of a personality: becoming and development in adolescence]. Kyiv : NPU imeni M. P. Drahomanova [in Ukrainian].

Tatenko, V. (2003). Sotsialno-psykholohichni mekhanizmy vplyvu liudyny na liudynu [The social-psychological mechanisms of person - person influence]. Sotsialna psykholohia - Social psychology, 1, 60-72 [in Ukrainian].

Bradley, B., Postlethwaite, B., Klotz, A., Hamdani, M., \& Brown, K. (2012). Reaping the Benefits of Task Conflict in Teams: The Critical Role of Team Psychological Safety Climate. Journal of Applied Psychology, 1, Vol. 97, 151-158. DOI 10.1037/a0024200.

Dafermos, M. (2018). Rethinking Cultural-Historical Theory: A Dialectical Perspective to Vygotsky. Singapore : Springer Nature Singapore Pte Ltd.

Piff, P., Dietze, P., Feinberg, M., Stancato, D., \& Keltner, D. (2015). Awe, the Small Self, and Prosocial Behavior. Journal of Personality and Social Psychology, 6, Vol. 108, 883-899. Retrieved from http:// dx.doi.org/10.1037/pspi0000018.

Stellar, J., Willer, R. (2018). Unethical and Inept? The Influence of Moral Information on Perceptions of Competence. Journal of Personality and Social Psychology, 2, Vol. 114, 195-210. Retrieved from http:// dx.doi.org/10.1037/pspa0000097.

\section{АНОТАЦІЯ}

У статті доведено, що інтерсуб'єктна взаємодія - це важлива частина психічного життя людини, пов'язана з особистісним спілкуванням, діями на благо інших і внутрішнім зростанням. Обгрунтовано методологічну основу для дослідження інтерсуб'єктності, якою в нашому 
дослідженні стала культурно-історична психологія Л. С. Виготського. Виявлено, що інтерсуб'єктність має тісні зв'язки зі смисловою сорерою особистості. Досліджено взаємозв'язок інтерсуб'єктності з соціально-психологічними характеристиками групи (груповою приналежністю, психологічною атмосферою) з використанням опитувальників. Виявлено досить сильні корелячійні зв'язки між досліджуваними змінними (інтерсуб'єктністю та соціально-психологічними особливостями групи). Виявлені емпіричні закономірності та кореляційні зв'язки опосередковано свідчать на користь того, що «Методика дослідження інтерсуб'єктності» М. М. Наконечної є надійним і валідним психодіагностичним інструментом. У процесі експериментального дослідження з модифікованою методикою психічного насичення було доведено, що ситуація інтерсуб'єктної взаємодії значною мірою впливає на виникнення позитивних переживань під час монотонної діяльності. Здійснено аналіз проведеного експериментального дослідження, яке включало в себе чотири етапи та припускало віднайдення відповідей на такі дослідницькі запитання: 1) Чи змінює включення смислу процес виконання монотонної діяльності? 2) Як інтерсуб'єктна взаємодія впливає на перебіг діяльності, що викликає психічне насичення? 3) Який зі смислів - смисл взаємодії з іншим, смисл професійного вдосконалення, смисл творчості - найбільще впливатиме на діяльність малювання одноманітних хрестиків? Доведено, що ситуація інтерсуб'єктної взаємодії сприймається учасниками принципово по-іншому, ніж ситуація одноосібної, моносуб'єктної діяльності. Виявлено, що переживання в ході інтерсуб'єктної взаємодії характеризувалися позитивним емоційним тлом. Підтверджено гіпотезу про те, що введення нових сенсів переструктуровує виконувану одноманітну діяльність.

Ключові слова: інтерсуб'єктна взаємодія, смисл, діяльність, особистість, спілкування, група.

\section{Наконечная Мария. Интерсубъектное взаимодействие в малых социальных группах}

\section{АННОТАЦИЯ}

В статье доказано, что интерсубъектное взаимодействие - это важная часть психической жизни человека, связанная с личностным общением, действиями на благо других и внутренним ростом. Обоснована методологическая база для исследования интерсубъектности, которой в настоящем исследовании стала культурно-историческая пси- 
хология Л. С. Выготского. Выявлено, что интерсубъектность имеет тесные связи со смысловой сферой личности. Была исследована взаимосвязь интерсубъектности с социально-психологическими характеристиками группы (групповой принадлежностью, психологической атмосферой) с использованием опросников. Выявлены достаточно сильные корреляционные связи между исследуемыми переменными (интерсубъектностью и социально-психологическими особенностями группы). Выявленные эмпирические закономерности и корреляционные связи опосредованно свидетельствуют в пользу того, что «Методика исследования интерсубъектности» М. М. Наконечной является надежным и валидным психодиагностическим инструментом. В процессе экспериментального исследования с модифицированной методикой психического насыщения было доказано, что ситуация интерсубъектного взаимодействия в значительной степени влияет на возникновение позитивных переживаний во время монотонной деятельности. Осуществлен анализ проведенного экспериментального исследования, которое включало в себя четыре этапа и предполагало нахождение ответов на следующие исследовательские вопросы: 1) Меняет ли включение смысла процесс выполнения монотонной деятельности? 2) Как интерсубъектное взаимодействие влияет на ход деятельности, вызывающей психическое насыщение? 3) Какой из смыслов - смысл взаимодействия с другим, смысл профессионального совершенствования, смысл творчества - будет больше всего влиять на деятельность рисования однообразных крестиков? Доказано, что ситуация интерсубъектного взаимодействия воспринимается участниками приниипиально по-другому, чем ситуация моносубъектной деятельности. Выявлено, что переживания в ходе интерсубъектного взаимодействия характеризовались позитивным эмоциональным фроном. Подтверждена гипотеза о том, что введение новых смыслов переструктурирует выполняемую однообразную деятельность.

Ключевые слова: интерсубъектное взаимодействие, смысл, деятельность, личность, общение, группа. 